\title{
Factors affecting knowledge governance implementation among Malaysian SMEs
}

\author{
Khong Sin Tan ${ }^{a^{*}}$, Yee Yen Yuen ${ }^{b}$ and Le Ngoc Ha
}

${ }^{a, b}$ Multimedia University, Malaysia

${ }^{c}$ European University, Malaysia

CH R O I CLE A B S T RACT

Article history:

Received: November 26, 2017

Received in revised format:

March 31, 2018

Accepted: April 4, 2018

Available online:

April 5, 2018

Keywords:

Knowledge Governance

IT Governance

Malaysia

\begin{abstract}
Knowledge governance is a relatively new discipline in Malaysia with very little research work performed so far. As Malaysian government is actively involved in the implementation of Economic Transformation Program (ETP), Government Transformation Program (GTP) and Urban Transformation Program (UTP), Small and Medium Enterprises (SMEs) need to react to the government move by transforming their conventional knowledge management practices to knowledge governance. As of today, there has been very limited study conducted in Malaysia on the extent of the company acceptance of such governance. This research was therefore conducted to measure the SME users' acceptance and identify the pros and cons of knowledge governance. With these findings, recommendations were given to policy makers and industries to increase the company's knowledge governance acceptance. Questionnaire was used for data collection. Systematic random sampling methods was used to select respondents. The questionnaire was developed and adapted based on knowledge management and IT governance frameworks. In this model, the dependent variable was company's intention to adopt knowledge governance. Independent variables included knowledge application needs, knowledge architecture, knowledge infrastructure, knowledge investment and knowledge principles.
\end{abstract}

\section{Introduction}

Knowledge governance is a type of governance method in an organization which focuses on improving knowledge management and control. Knowledge governance is a subset towards the whole governance system in enterprise and corporation. In organization, there are knowledge management governance and information technology governance. Knowledge governance comprising of both knowledge management governance and information technology governance whereas knowledge governance is a system that governs important knowledge operational sectors inside the company.

\subsection{Background of Research}

Knowledge is an asset for any organization. This fact is particularly reflected in Malaysia's road maps when Malaysian government plans to achieve the status as developed country in 2020. In order to achieve the Vision 2020, Malaysian government realizes that the nation needs to produce as many * Corresponding author.

E-mail address: kstan@mmu.edu.my (K. Sin Tan) 
knowledge workers as possible (MIMOS, 2004). These knowledge workers is targeted to be transformed to value-based knowledge workers to enable Malaysia to be known as a developed country by the year 2020. In conjunction with Malaysia's vision to create knowledge workers, it is evident that knowledge plays an important role in the progress and development of the country. However, the challenge of knowledge management is not on its creation. It is more on knowledge capture and integration of knowledge (Davenport, 1997; Grant, 1996). Indeed, knowledge has limited organizational value if knowledge is not shared among people or organizations. The ability to integrate and apply specialized knowledge of organizational members is fundamental to a firm's ability to create and sustain competitive advantage (Grant, 1996).

While Malaysia is moving towards generating more and more knowledge workers in knowledge-typed organizations, it is imperative for Malaysia government to outline proper knowledge governance in the country. Knowledge governance should be treated as important as corporate governance in any organization. At this moment, there is very limited study on knowledge governance particularly in Malaysia. Good knowledge governance is a key factor to ensure success across different business clusters (Menkhoff, 2011). As one of the most concerted efforts to assist Malaysian government in realizing the key objective of Vision 2020, building a knowledge society, this study intends to address the following research questions:

1) What are the factors that either inhibit or encourage knowledge governance among SME users in Malaysia?

2) How to develop a knowledge governance framework to suit Malaysia's knowledge management environment?

\subsection{Objectives of Research}

In this study, the main objective is to investigate the implementation of knowledge governance among Malaysian SMEs (Kaushik \& Kumar, 2017). This study aims to investigate factors that either inhibit or encourage knowledge governance among SME users in Malaysia. This study is interested in investigating the tacit and explicit knowledge kept by SMEs in the company computers, database and software and also the management and control of corporate knowledge that is disseminated through Internet, Intranet or Extranet.

\section{Literature Review}

\subsection{Knowledge Management (KM) Governance}

Zyngier et al. $(2004,2005,2006)$ developed a framework which conceptualizes the knowledge management (KM) strategy development and implementation processes as core aspects of KM governance. The researchers specifically focused on aspects of risk management and evaluation processes. Strong leadership is crucial for the success of KM initiatives (Chourides et al., 2003; Scarborough et al., 1999; Storey \& Barnett, 2000) particularly for senior managers (Davenport \& Prusak, 1998; Mason \& Pauleen, 2003; Skyrme \& Amidon, 1997; Soliman \& Spooner, 2000) to serve as role models (Scarborough et al., 1999; Gandhi et al., 2018), as well as architects and catalysts (Inkpen, 1996) for the KM success in the organization.

KM governance describes structures and processes which have been developed to undertake, coordinate and control KM activities in the organization (Smith \& McKeen, 2003). More specifically, knowledge governance describes the structuring of the KM function, the distribution of KM decisionmaking rights, and responsibilities among enterprise stakeholders, as well as the structures and processes for making and monitoring strategic decisions (Peterson, 2004). International scholar such as Ju Choi et al. (2005) opined that companies need to accept multiple governance structure for successful 
knowledge transfer. Another foreign researchers, Schroeder and Pauleen (2007) outlined KM governance structures and KM governance processes. According to the researchers, KM governance structures can be divided into governance structure (information management center) and KM projects and services (document management systems, expert system and contact management system). Without appropriate attention to knowledge creation and utilization within decision-making processes, companies will fall into "knowledge trap" (Menkhoff, 2011) and governance will be undermined (Blackman $\&$ Kennedy, 2009). Fig. 1 shows the knowledge governance framework.

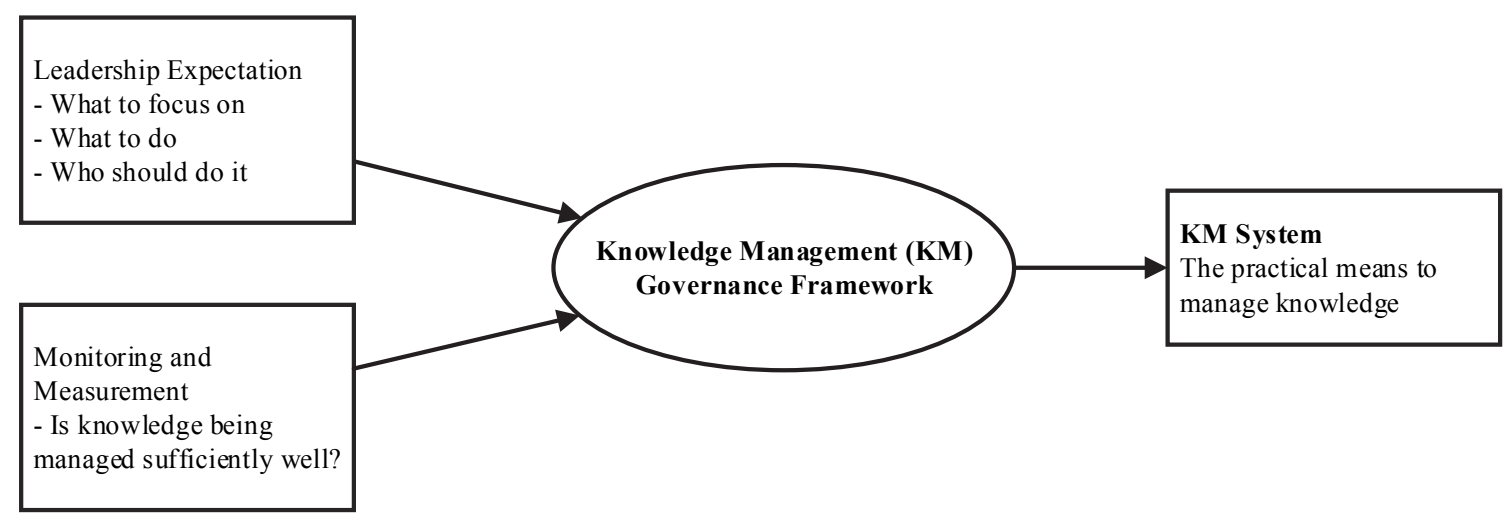

Fig. 1. Knowledge Management (KM) Governance Framework

\subsection{Information Technology (IT) Governance}

Information technology (IT) governance is a system of checks and balances between management and shareholders to ensure sustainable long-term value in the organisation's operation. It is primarily driven by the need for transparency of the organisation's risks and the protection of shareholder's values. Good IT governance benefits the organization. According to Newell and Wilson (2002), IT governance increases the market valuation of companies by improving their financial performance, reducing the risk that board of directors will make self-serving decisions, and raising investor confidence. The scholars found that professional investors are willing to pay a premium of as much as $28 \%$ percent for the shares of well-governed companies. IT Governance describes who makes which decisions, who provides inputs and analyzes the issues, who sets priorities, and who settles disputes when there is no clear consensus. Good governance processes are actively designed and well understood by participants, and foster timely decisions that can be communicated effectively.

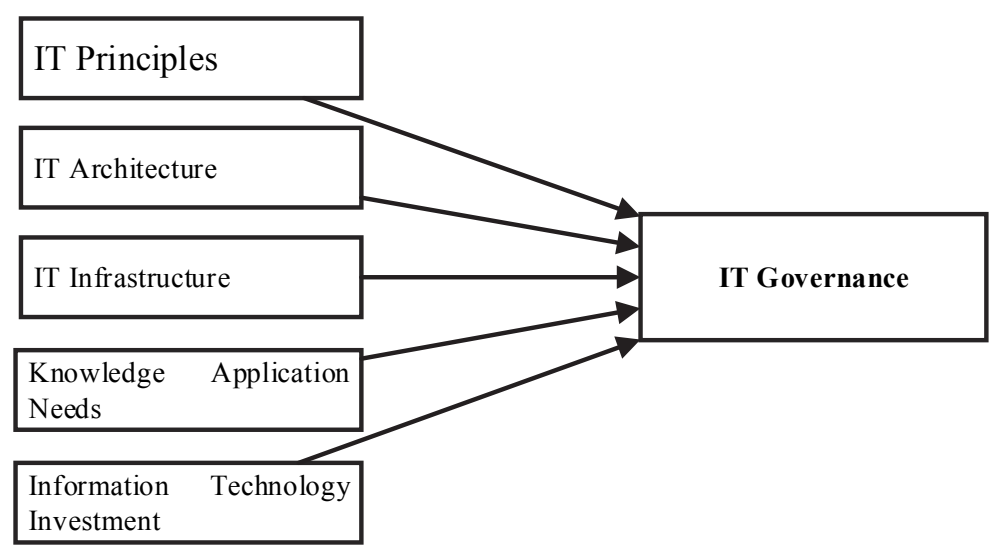

Fig. 2. Information Technology Governance Framework 
A good planning in IT governance provides a clear and transparent IT decision making process which helps the top management to achieve their vision besides maintaining their creativity. Governance experiences can be learned from those companies which achieve their targets through internal IT services or data centers. Governance has been described as an integral part of IT management. Besides, regular compliance, IT governance also concerns about the organization structure and the process which cause the relevant business results in return. Governance is needed to be achieve an effective business results with the support of efficient execution and resources. Fig. 2 indicates the framework for information technology governance.

\section{Methodology/Materials}

\subsection{Research Framework}

Fig. 3 shows the proposed knowledge governance framework of this study. This research framework is a holistic framework, integrating essential constructs of the knowledge management government framework (Fig. 1) and information technology government framework (Fig. 2). This study is the pioneer study in Malaysia that propose this framework to test the key factors affecting knowledge governance implementation in SMEs.

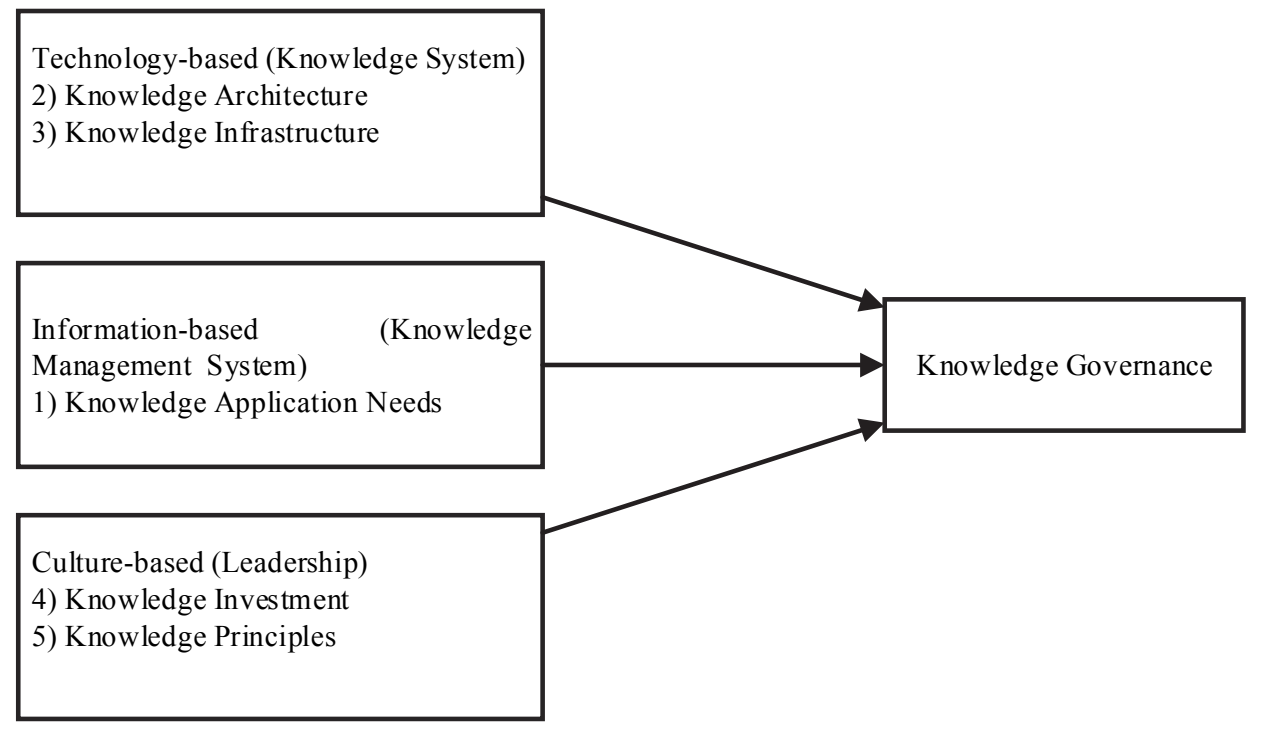

\subsection{Research Hypotheses}

Fig. 3. Knowledge Governance Framework

Based on proposed research framework above, five hypotheses were formed to examine the relationship between independent variables towards knowledge governance.

H1: There is a relationship between knowledge application needs and knowledge governance.

$\mathrm{H} 2$ : There is a relationship between knowledge architecture and knowledge governance.

H3: There is a relationship between knowledge infrastructure and knowledge governance.

H4: There is a relationship between knowledge investment and knowledge governance.

H5: There is a relationship between knowledge principles and knowledge governance.

\subsection{Data Collection Methods}

Questionnaire was used for data collection in this study. Convenience sampling method was used to select 25 companies from Melaka in pilot study. Previous studies (Hair et al., 1995; Hulland et al., 
1996; Kline, 2015) stated that a sample size of 100 is considered small, between 100 and 200 is considered medium, and more than 200 is considered large. Roscoe (1975) proposed the rule of thumb to follow when determining sample size, which is the number of participants in a questionnaire should be larger than 30 and less than 500. Roscoe (1975) mentioned that in multivariate research like multiple regression analysis, the sample size should be at least preferably 10 times or more as large as the number of variables in the study. In this study, there are a total of 10 independent and dependent variables for multiple regression analyses. Therefore, the sample size of 781 is appropriate. This study follows strictly all the rules of thumbs to ensure reliable data generation and analyses at the ensuing stage. A total number of 781 complete data were collected.

A total of 36 questions were included in a six part section of the questionnaire. The parts are Section A which includes the general/demographics questions, Section B inquires about independent variables and Section $\mathrm{C}$ soliciting for response towards dependent variable. General question focuses on the demographic aspects of the respondents such as age, gender, ethnic group, nationality, educational level, and working experience. Section B focuses on items measuring "knowledge application needs", "knowledge architecture", "knowledge infrastructure", "knowledge investment" and "knowledge principles". The questions are designed using five-point Likert-Scale with a rating varying from 1="Strongly disagree", 2="Disagree", 3="Neutral", 4="Agree" and 5="Strongly agree". Section C of the questionnaire measures "knowledge governance" using five-point Likert scale. According to researchers (Sekaran \& Bougie, 2003; Walsh \& Betz, 1995; Zikmund, 2000), reliability involves the extent to which the instrument measures without bias (error free) and offers similar results over time and across the various items in the instrument. To ensure internal consistency or reliability, coefficient alpha or Cronbach's alpha is used. Nunnally (1978) suggested that a minimum alpha of 0.6 suffice for early stages of research. The use of Cronbach's coefficient is the most common method used for assessing the reliability of a measurement scale with multi-point items (Hayes, 1998). According to Malhotra (2008), this coefficient varies from 0 to 1 and a Cronbach's alpha value of 0.6 or less generally indicates unsatisfactory consistency or reliability.

\section{Results and Findings}

\subsection{Respondents' Profile}

Table 1 shows the numbers and states of respondents participated in this study. There are a total of 781 respondents from ten states of Malaysia participated in this empirical study.

\section{Table 1}

States of Respondents

\begin{tabular}{llcc}
\hline No & States & Frequency & Percent (\%) \\
\hline 1 & Johor & 80 & 10.2 \\
2 & Melaka & 125 & 16.0 \\
3 & Selangor & 96 & 12.3 \\
4 & Perak & 86 & 11.0 \\
5 & Penang & 84 & 10.8 \\
6 & Kelantan & 102 & 13.1 \\
7 & Terengganu & 98 & 12.5 \\
8 & Pahang & 110 & 14.1 \\
\hline & Total & 781 & 100.0 \\
\hline
\end{tabular}

Table 2 shows the age of respondents. Most of the respondents are between 41 to 50 years old (256 respondents or 32.8 percent). Two hundred and thirty five (235 respondents or 30.1 percent) respondents' age are between $31-40$ and one hundred and eighty five respondents are between $<20$ to 30 (185 respondents or 23.7 percent). One hundred five respondents ( 105 respondents or 13.4 percent) age more than 50 . 


\section{Table 2}

Age of Respondents

\begin{tabular}{lccc}
\hline & Age & Frequency & Percent (\%) \\
\hline$<20-30$ & & 185 & 23.7 \\
$31-40$ & 235 & 30.1 \\
$41-50$ & 256 & 32.8 \\
$>50$ & 105 & 13.4 \\
\hline Total & 781 & 100.0 \\
\hline
\end{tabular}

Table 3 shows the gender of respondents. Five hundred and sixty eight respondents ( 72.7 percent) are male and three hundred and two hundred and thirteen respondents (27.3 percent) are female.

Table 3

Gender of Respondents

\begin{tabular}{lccc}
\hline & Gender & Frequency & Percent (\%) \\
\hline Male & 568 & 72.7 \\
Female & 213 & 27.3 \\
\hline
\end{tabular}

Table 4 shows that 289 Malay respondents (37.0 percent) participated in this study. Three hundred seventy six respondents (48.1 percent) are Chinese and one hundred sixteen respondents (14.9 percent) are Indians.

Table 4

Ethnic Groups of Respondents

\begin{tabular}{ccc}
\hline Ethnicity & Frequency & Percent(\%) \\
\hline Malay & 289 & 37.0 \\
Chinese & 376 & 48.1 \\
Indian & 116 & 14.9 \\
\hline
\end{tabular}

Table 5 indicates that all 781 respondents are Malaysians.

Table 5

Nationality of Respondents

\begin{tabular}{ccc}
\hline Nationality & Frequency & Percent (\%) \\
\hline Malaysian & 781 & 100.0 \\
\hline
\end{tabular}

Table 6 indicates that most of the respondents ( 635 respondents or 81.3 percent) are with Bachelor's degree. One hundred and twenty five respondents $(16.0$ percent $)$ are holding diploma or advanced diploma certificate and twenty one (2.7 percent) are having SPM/SPMV/STPM certificate.

\section{Table 6}

Educational Level of Respondents

\begin{tabular}{lcc}
\hline Education Level & Frequency & Percent (\%) \\
\hline SPM/SPMV/STPM & 21 & 2.7 \\
Diploma/Advanced Diploma & 125 & 16.0 \\
Bachelor's Degree & 635 & 81.3 \\
\hline
\end{tabular}

Table 7 indicates that most of the respondents (352 respondents or 45.1 percent) had 2 to 5 working year experiences. One hundred and eighty seven respondents (23.9 percent) had less than two years' working experience. One hundred and fifty seven respondents $(20.1$ percent $)$ had $6-10$ working year of experience. Eighty five respondents (10.9 percent) had more than 10-year working experience. 
Table 7

Working Experience of Respondents

\begin{tabular}{lcc}
\hline \multicolumn{1}{c}{ Years of Working Experience } & Frequency & Percent \\
\hline$<2$ years & 187 & 23.9 \\
$2-5$ years & 352 & 45.1 \\
$6-10$ years & 157 & 20.1 \\
$>10$ years & 85 & 10.9 \\
\hline
\end{tabular}

\subsection{Descriptive Statistics}

Table 8 indicates the mean values and standard deviations for items measuring knowledge application needs in the questionnaire. "My company feels the need to use calculation software like Excel to manage worksheet" has the highest mean of 4.90 out of 5.00 and "My company feels the need to use presentation software like PowerPoint to manage presentation documents." has the highest mean of 4.16 out of 5.00 .

Table 8

Mean and Standard Deviation for "Knowledge Application Needs"

\begin{tabular}{lcc}
\hline \multicolumn{1}{c}{ Knowledge Application Needs } & Mean & Std. Dev. \\
\hline $\begin{array}{l}\text { My company feels the need to use word software like Word to manage } \\
\text { document. }\end{array}$ & 4.76 & 0.360 \\
$\begin{array}{l}\text { My company feels the need to use calculation software like Excel to } \\
\text { manage worksheet. }\end{array}$ & 4.90 & 0.450 \\
$\begin{array}{l}\text { My company feels the need to use presentation software like PowerPoint } \\
\text { to manage presentation documents. }\end{array}$ & 4.16 & 0.654 \\
$\begin{array}{l}\text { My company feels the need to use network to coordinate information flows } \\
\text { between staff. }\end{array}$ & 4.25 & 0.652 \\
\begin{tabular}{l} 
My company feels the need to have server to store all softcopy documents. \\
\hline
\end{tabular} & 4.34 & 0.698 \\
\hline
\end{tabular}

Table 9 shows the mean values and standard deviations for knowledge architecture. "My company has information in place where I can access from home through Internet." has the most positive mean rating of 4.35 while "My company has information in place where I can access from home through mobile phone." has the lowest mean rating of 3.95 out of 5 .

\section{Table 9}

Mean and Standard Deviation for "Knowledge Architecture"

\begin{tabular}{lcc}
\multicolumn{1}{c}{ Knowledge Architecture } & Mean & Std. Dev. \\
\hline My company has well-designed network structure how information flows. & 4.20 & 0.450 \\
My company has social intranet for sharing information. & 4.12 & 0.360 \\
My company has all documents in one place like server to share among staff. & 4.25 & 0.450 \\
$\begin{array}{l}\text { My company has information in place where I can access from home through Internet. } \\
\text { My company has information in place where I can access from home through mobile } \\
\text { phone. }\end{array}$ & 4.35 & 0.246 \\
& & 0.854 \\
\hline
\end{tabular}

Table 10 indicates the mean values and standard deviations for knowledge infrastructure. "My company feels the need to use calculation software like Excel to manage worksheet." has the highest mean of 4.90 and "My company feels the need to use network to coordinate information flows between staff." has the lowest mean of 4.25 .

Table 11 indicates the mean values and standard deviations for knowledge principles."My company has rules and regulations how information flows in the company" has the lowest mean of 3.65 and "My 
company wants every staff knows that it is important not to disclose any private and confidential." has the highest mean of 4.47 .

\section{Table 10}

Mean and Standard Deviation for "Knowledge Infrastructure"

\begin{tabular}{lcc}
\hline Knowledge Infrastructure & Mean & Std. Dev. \\
\hline My company feels the need to use word software like Word to manage document. & 4.76 & 0.360 \\
My company feels the need to use calculation software like Excel to manage worksheet. & 4.90 & 0.450 \\
$\begin{array}{l}\text { My company feels the need to use presentation software like PowerPoint to manage } \\
\text { presentation documents. }\end{array}$ & 4.16 & 0.654 \\
My company feels the need to use network to coordinate information flows between staff. & 4.25 & 0.652 \\
\hline My company feels the need to have server to store all softcopy documents. & 4.34 & 0.698 \\
\hline
\end{tabular}

\section{Table 11}

Mean and Standard Deviation for "Knowledge Principles"

\begin{tabular}{lcc}
\hline Knowledge Principles & Mean & Std. Dev. \\
\hline My company has the rules and regulations how to keep softcopy of documents. & 3.65 & 0.352 \\
My company has proper document control. & 3.86 & 0.358 \\
My company requires all staff to save their documents in computer server. & 3.96 & 0.457 \\
My company has rules and regulations how information flows in the company. & 4.05 & 0.485 \\
$\begin{array}{l}\text { My company wants every staff knows that it is important not to disclose any private } \\
\text { and confidential. }\end{array}$ & 4.47 & 0.546 \\
\hline
\end{tabular}

Table 12 shows the mean values and standard deviations for knowledge investment. "My company purchases software like Microsoft Office for staff to use." has the highest mean of 4.56 and "My company send staff for training." has the lowest mean of 4.04.

\section{Table 12}

Mean and Standard Deviation for "Knowledge Investment"

\begin{tabular}{lcc}
\hline Knowledge Investment & Mean & Std. Dev. \\
\hline My company send staff for training. & 4.04 & 0.385 \\
My company purchases software like Microsoft Office for staff to use. & 4.56 & 0.345 \\
My company has proper computer network to link up all & 3.95 & 0.385 \\
My company spends money in controlling knowledge flow in the company. & 4.26 & 0.256 \\
My company encourage staff to apply and attend training, workshop or seminar. & 4.11 & 0.645 \\
\hline
\end{tabular}

Table 13 shows the mean values and standard deviations for knowledge investment. "My company feels the need to secure the knowledge in company." has the highest mean of 4.78 and "My company feels the need to monitor knowledge in company." has the lowest mean of 4.14.

\section{Table 13}

Mean and Standard Deviation for "Knowledge Governance"

\begin{tabular}{lcc}
\hline Knowledge Governance & Mean & Std. Dev. \\
\hline My company feels the need to manage knowledge in company. & 4.55 & 0.854 \\
My company feels the need to control knowledge in company. & 4.48 & 0.562 \\
My company feels the need to add value to the knowledge in company & 4.36 & 0.265 \\
My company feels the need to secure the knowledge in company. & 4.78 & 0.854 \\
My company feels the need to monitor knowledge in company. & 4.14 & 0.854 \\
\hline
\end{tabular}

Table 14 shows the Cronbach's Alpha values for all the independent variables. All of the values are above 0.7 and thus all the variables are reliable. 
Table 14

Cronbach Alpha's Values

\begin{tabular}{lcc}
\hline Variables & Items & Cronbach Alpha \\
\hline Knowledge Application Needs & 5 & 0.879 \\
Knowledge Architecture & 5 & 0.765 \\
Knowledge Infrastructure & 5 & 0.843 \\
Knowledge Investment & 5 & 0.856 \\
Knowledge Principles & 5 & 0.823 \\
\hline
\end{tabular}

\subsection{Multiple Linear Regression}

Fig. 4 shows the normal P-P plot of regression standardized residual for knowledge governance. The five independent variables are normally distributed. Therefore, multiple linear regression can be used to study the strength relationship between the five independent variables on knowledge governance.

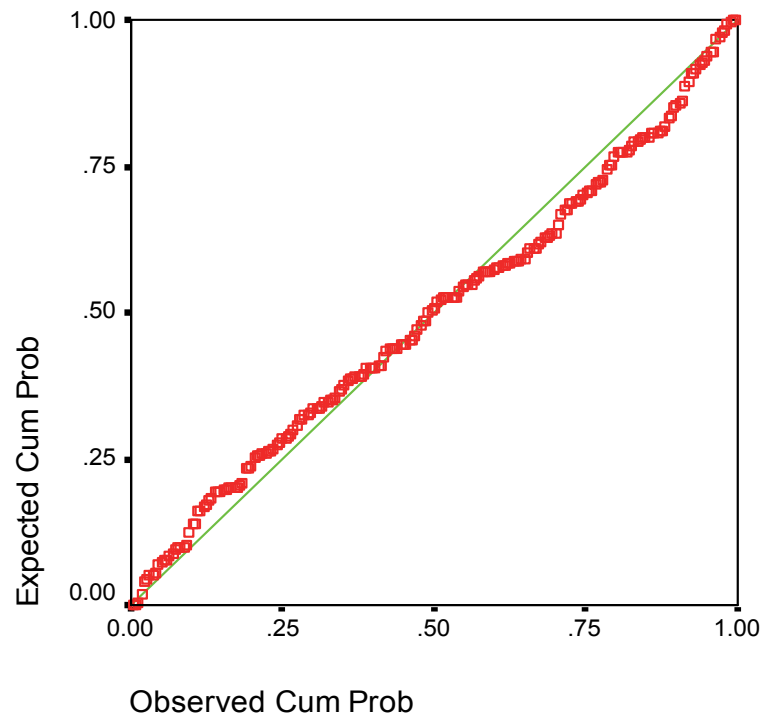

Fig. 4. Normal P-P Plot of Regression Standardized Residual for Knowledge Governance

Table 15 shows the results of multiple linear regression of the five key knowledge issues on knowledge governance. Knowledge application needs and knowledge investment are significantly related to knowledge governance. Knowledge architecture, knowledge infrastructure and knowledge principles are not significantly related to knowledge governance. This model explains 65.2 per cent of the variation in knowledge governance.

\section{Table 15}

MLR for Knowledge Governance

\begin{tabular}{lccccccc}
\hline & \multicolumn{2}{c}{ Unstd. Coeff. } & $\begin{array}{c}\text { Std. } \\
\text { Coeff. }\end{array}$ & t & Sig. & \multicolumn{2}{c}{$\begin{array}{c}\text { Collinearity } \\
\text { Statistics }\end{array}$} \\
\cline { 2 - 8 } & B & Std. Err. & Beta & & & Tole. & VIF \\
\hline (Constant) & .366 & .198 & & 4.369 & .001 & & \\
Knowledge Application Needs & .246 & .085 & .365 & 3.652 & .001 & .433 & 2.542 \\
Knowledge Architecture & .283 & .137 & .265 & 1.824 & .058 & .358 & 3.945 \\
Knowledge Infrastructure & .452 & .122 & .045 & 0.562 & .520 & .379 & 3.365 \\
Knowledge Investment & .235 & .094 & .420 & 3.652 & .001 & .365 & 3.884 \\
Knowledge Principles & .246 & .098 & .056 & 0.288 & .751 & .365 & 3.252 \\
\hline
\end{tabular}

\section{$\mathrm{F}=56.482$ Sig. $=.000$}

R Sqr. $=0.652$

Dependent Variable: Knowledge Governance

4.5 Summary of Hypotheses Findings 
Table 16 summarizes the findings for the research hypotheses.

Table 16

Summary of Findings

\begin{tabular}{llc}
\hline No & Hypothesis & Finding \\
\hline H1 & There is a relationship between knowledge application needs and knowledge governance & Accepted \\
H2 & There is a relationship between knowledge architecture and knowledge governance & Rejected \\
H3 & There is a relationship between knowledge infrastructure and knowledge governance & Rejected \\
H4 & There is a relationship between knowledge investment and knowledge governance & Accepted \\
H5 & There is a relationship between knowledge principles and knowledge governance & Rejected \\
\hline
\end{tabular}

\section{Conclusion}

\subsection{Assessment of Research Objective}

The objective is to investigate the factors that either inhibit or encourage knowledge governance among SME users in Malaysia. The findings of this study have shown that only two knowledge dimensions were related to knowledge governance model. Knowledge application needs and knowledge investment are important dimensions. Thus, if SMEs have intention to develop knowledge governance model in the company, SMEs must focus on the needs of knowledge and invest money in knowledge development and control. The respondents perceive knowledge architecture, knowledge principles and knowledge infrastructure as unimportant determinants that do not significantly affect knowledge governance due to the belief that knowledge management and control has little value to the future growth of the company. The SMEs will consider for knowledge architecture, infrastructure and control only when they have excess money. Otherwise, SMEs would like to put more resources in production rather than in managing knowledge.

Thus, Malaysian government could assist SMEs in terms of hardware and software to develop knowledge governance and controls in the companies. Malaysian government could provide hardware or software subsidies to SMEs to implement knowledge governance. Moreover, Malaysian government, NGOs and SMEs could jointly conduct seminars or workshops around the nation to raise the awareness of SMEs on the importance of knowledge governance. In order to increase knowledge governance awareness among companies, government or respective agencies can advertise through media such as television, radio or banners to highlight the advantages of using knowledge governance in business. Moreover, government can conduct workshops or seminars to educate organizations on the importance of knowledge governance. The implementation of knowledge governance in organization can become one of the criteria in key performance indicator when government assesses the performance of any organization. Thus, this motive can motivate organizations to adopt knowledge governance.

\subsection{Implications for Practice}

The proposed research model of this study has significant implications for the industry and government as it is one of the pioneer models measuring knowledge governance in Malaysia with 65.2 per cent of the variation in knowledge governance are explained by the knowledge dimensions stipulated on the model. Moreover, the findings of this research indicate that knowledge application needs and knowledge investment influence on the implementation of knowledge governance. Thus, SMEs are concerned with the types of knowledge applications they need to use for manage knowledge. Moreover, they are concerned with the money invested in knowledge governance. "Is it worthwhile to invest money in knowledge governance while it seems that knowledge governance is optional?" "Should company consider first investment in production or knowledge governance when capital is a constraint?" These 2 questions will greatly assist the industry practitioners and government in drafting future blueprint or policy associated with knowledge government. 


\subsection{Agenda for Future Research}

Future studies can focus on internal factors that may affect knowledge governance. For example, researchers can investigate internal factors such as owners' academic qualifications, family background and others. Future studies can also focus on comparisons of knowledge governance adoption between Malaysia and other developing countries like Singapore, Thailand, Vietnam, Indonesia and the Philippines.

\section{References}

Blackman, D., \& Kennedy, M. (2009). Knowledge management and effective university governance. Journal of Knowledge Management, 13(6), 547-563.

Chourides, P., Longbottom, D., \& Murphy, W. (2003). Excellence in knowledge management: an empirical study to identify critical factors and performance measures. Measuring Business Excellence, 7(2), 29-45.

Davenport, T. H. (1997). Ten principles of knowledge management and four case studies. Knowledge and process Management, 4(3), 187-208.

Davenport, T. H., \& Prusak, L. (1998). Working knowledge: How organizations manage what they know: Harvard Business Press.

Gandhi, S., Sachdeva, A \& Gupta, A. (2018). Distributor service quality in Indian SMEs: A bidirectional customer perspective. Uncertain Supply Chain Management, 6(4), 335-356.

Grant, R. M. (1996). Prospering in dynamically-competitive environments: Organizational capability as knowledge integration. Organization science, 7(4), 375-387.

Hair, J., Anderson, R., Tatham, R., \& Black, W. (1995). Multivariable data analysis reading. In: USA: Prentice Hall International Editions.

Hayes, B. E. (1998). Measuring customer satisfaction: Survey design, use, and statistical analysis methods: ASQ Quality Press.

Hulland, J., Chow, Y. H., \& Lam, S. (1996). Use of causal models in marketing research: A review. International Journal of Research in Marketing, 13(2), 181-197.

Inkpen, A. C. (1996). Creating knowledge through collaboration. California Management Review, 39(1), 123-140.

Ju Choi, C., Cheng, P., Hilton, B., \& Russell, E. (2005). Knowledge governance. Journal of knowledge Management, 9(6), 67-75.

Kaushik, P., \& Kumar, S. (2017). An application of six sigma for SMEs: A case study. Management Science Letters, 7(3), 145-152.

Kline, R. B. (2015). Principles and practice of structural equation modeling: Guilford publications.

Malhotra, N. K. (2008). Marketing research: An applied orientation, 5/e: Pearson Education India.

Mason, D., \& Pauleen, D. J. (2003). Perceptions of knowledge management: A qualitative analysis. Journal of Knowledge Management, 7(4), 38-48.

Menkhoff, T. (2011). Beyond the knowledge trap: Developing asia's knowledge-based economies: World Scientific.

Newell, R., \& Wilson, G. (2002). A premium for good governance. McKinsey Quarterly, 3(2), 20-23.

Nunnally, J. (1978). Psychometric Theory (2nd Edit.) McGraw-Hill. Hillsdale, NJ.

Peterson, R. R. (2004). Integration strategies and tactics for information technology governance. Strategies for information technology governance, 2, 37-80.

Roscoe, J. T. (1975). Fundamental research statistics for the behavioral sciences [by] John T. Roscoe.

Scarborough, H., Swan, J., \& Preston, J. (1999). Knowledge management-the next fad to forget people. Paper presented at the Proceedings of European Conference on Information Systems, Copenhagen.

Schroeder, A., \& Pauleen, D. (2007). KM governance: investigating the case of a knowledge intensive research organisation. Journal of Enterprise Information Management, 20(4), 414-431.

Sekaran, U., \& Bougie, R. (2003). Research Methods for Business: A Skill-building Approach. USA: John Willey \& Sons. In: Inc. 
Skyrme, D., \& Amidon, D. (1997). The knowledge agenda. Journal of Knowledge Management, 1(1), 27-37.

Smith, H. A., \& McKeen, J. D. (2003). Developments in Practice IX: The evolution of the KM function. Communications of the Association for Information Systems, 12(1), 4.

Soliman, F., \& Spooner, K. (2000). Strategies for implementing knowledge management: role of human resources management. Journal of Knowledge Management, 4(4), 337-345.

Storey, J., \& Barnett, E. (2000). Knowledge management initiatives: learning from failure. Journal of knowledge management, 4(2), 145-156.

Walsh, W. B., \& Betz, N. E. (1995). Tests and assessment: Prentice-Hall, Inc.

Zikmund, W. (2000). Mail Questionnaires vs. telephone interview. Exploring Marketing Research, Burgin, KY, USA.

Zyngier, S., Burstein, F., \& McKay, J. (2004). Knowledge Management Governance: A Multifaceted Approacho to Organisational Decision and Innovation Support-School of Information Management and Systems. Monash University, Melbourne, Austrália.

Zyngier, S., Burstein, F., \& McKay, J. (2005). Governance of Strategies to Manage Organizational Knowledge: A Mechanism to Oversee Knowledge Needs. In Case studies in knowledge management (pp. 83-103): IGI Global.

Zyngier, S., Burstein, F., \& McKay, J. (2006). The role of knowledge management governance in the implementation of strategy. Paper presented at the System Sciences, 2006. HICSS'06. Proceedings of the 39th Annual Hawaii International Conference on.

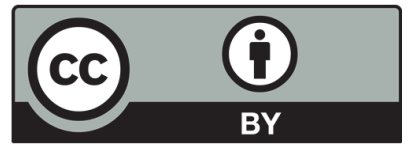

(C) 2018 by the authors; licensee Growing Science, Canada. This is an open access article distributed under the terms and conditions of the Creative Commons Attribution (CC-BY) license (http://creativecommons.org/licenses/by/4.0/). 